\title{
METALS IN SELECT BEERS COMMERCIALLY AVAILABLE IN THE US: UNMONITORED SOURCES OF CONCERNING EXPOSURE
}

\author{
Jasmina Markovski ${ }^{1}$, Miloš Markovski ${ }^{1}$, Branislav Knežević ${ }^{2}$ Kiril D. Hristovski ${ }^{1}$ \\ ${ }^{1}$ The Polytechnic School, Ira A. Fulton Schools of Engineering, Arizona State University, \\ 7171 E. Sonoran Arroyo Mall, Mesa, AZ 85212, United States \\ ${ }^{2}$ Faculty of Agriculture, University of Priština in Kosovska Mitrovica, Kopaonička bb, \\ 38228 Lešak, Serbia
}

Kiril.Hristovski@asu.edu

\begin{abstract}
Stemming from the need to inform US consumers about the potential health hazards originating from regulatory deficiencies and an inadequate capacity to conduct the complete screening of beverage products entering the US, this study aimed to answer two questions: (1) how do concerning metal concentrations of beers imported to the US market compare to those in US produced beers; and (2) do imported and domestic beers exhibit concerning metal concentrations below the existing US primary drinking water standards. To address this aim: (1) beers manufactured worldwide, which were commercially available on the US market were obtained; (2) the concentration of concerning metals in the beers was analyzed; and (3) data were examined and correlated to explore any US maximum contaminant level (MCL) exceedances and determine whether geographic or grain-related trends exist. The results showed that there are no significant differences between the concerning metal concentrations of imported vs. domestic beers in the US market. Some specific heavy metals, like arsenic, are present in both imported and domestic beers in concentrations that exceed the national primary drinking water standards MCLs. Although water quality may be a factor contributing to the elevated concentrations of concerning metals in beers, it is more likely that the grain ingredients are greater contributors to the observed trends.
\end{abstract}

Keywords: national drinking water standards; health risks; country of origin; grain type ingredient

\section{МЕТАЛИ ВО ОДРЕДЕНИ КОМЕРЦИЈАЛНО ДОСТАПНИ ПИВА ВО САД: НЕМОНИТОРИРАНИ ИЗВОРИ НА ЗАГРИЖУВАЧКА ИЗЛОЖЕНОСТ}

Тргнувајќи од потребата за информирање на потрошувачите во САД во врска со потенцијалните ризици по здравјето кои произлегуваат од недостигот на прописи и несоодветен капацитет за спроведување на сеопфатно проверување на пијалаците во САД, оваа студија има за цел да одговори на две прашања: (1) каков е односот на концентрациите на металите во увозните пива на пазарот во САД во споредба со пивата произведени во САД; (2) дали концентрациите на металите во увозните и домашните пива се помали од постојните основни стандарди за водата за пиење. За да се оствари целта: (1) ги набавивме пивата кои се достапни на пазарот во САД, а произведени во странство; (2) беше анализирана концентрацијата на металите во пивата; (3) податоците беа испитани, како и заемната врска, со цел да се истражи дали постои пречекорување на некое максимално загадувачко ниво според стандардите на CAД (MCL) и да се утврди дали постојат трендови поврзани со географското потекло или со користените житарки. Резултатите покажаа дека не постојат значителни разлики во односот на концентрациите на металите помеѓу увозните и домашните пива кои можат да се најдат на пазарот во САД. Некои специфични тешки метали, на пример арсенот, се присутни, како во увозните така и во домашните пива, во концентрации кои ги пречекоруваат националните основни стандарди за водата за пиење (MCL). Иако квалитетот на водата може да биде виновен за покачените вредности на концентрациите на 
металите во пивото, поголема е веројатноста дека состојките во житарките во голема мера придонесуваат во забележаните трендови.

Клучни зборови: национални стандарди за водата за пиење; ризици по здравјето; земја на потекло; состав на видот на житарките

\section{INTRODUCTION}

With the growth of the open market economy and the influx of international food and beverage $(F \& B)$ products into the US, the existing capacity of responsible agencies which monitor the quality of these products has been rendered insufficient [1-3]. It is widely suspected that the quality of many commercially available $\mathrm{F} \& \mathrm{~B}$ products is not adequately monitored, which opens up avenues for the introduction of questionable quality food and beverage products on the US market. Recent findings about high concerning metal concentrations in some commercially available $\mathrm{F} \& \mathrm{~B}$ products have raised health-related concerns among the general population [4-7]. In particular, it was found that some beverages, which are part of a typical diet in the US, exhibit concerning metal concentrations in excess of the promulgated maximum contaminant levels (MCLs) for potable water [8-12].

In the US, beer represents an especially sensitive diet category among adult Americans [13, 14]. With 110 liters of beer being annually consumed per adult American, which corresponds to the recommendation for moderate alcohol consumption of 1 "12 ounce" beer drink per day for women, the presence of concerning metals in this popular beverage could significantly contribute to the risks associated with exposure to concerning metals via the oral route $[15,16]$. The main beer ingredients, like water and grain, represent the most likely sources of concerning metals in this beverage $[17,18]$. While concerning metal contamination of water has been well recognized and widely studied, the ability of some plants, which are used in the production of beer, to concentrate and accumulate concerning metal contaminants from the growth matrix (soil and/or water) has not been fully clarified. Arsenic, chromium, lithium, lead and mercury are just some of the highly toxic elements found to readily accumulate in crops [19, 20]. Although many environmental factors affect the accumulation of contaminants, it seems highly likely that specific plants have unique selectivity towards specific elements [21, 22]. For example, a recent publication by the United States Food and Drug Administration (FDA) generated significant attention when it was reported that rice has higher levels of inorganic arsenic than other foods [23]. Interestingly, however, the FDA noted that further beer testing was not planned, although rice could be considered as one of the main arsenic contributors to rice beers [24].

Although dietary exposures to concerning metal contaminants present in beer are unlikely to constitute an equal hazard to the consumers' health as the intake of water would, the potential impacts of beer quality on human health should not be neglected as beer accounts for over a dozen percent of the total daily beverage intake [16]. In the US alone, for example, 196 million barrels of beer were produced in 2012 [15], which has the ability to generate over $\$ 91.6$ billion per year [25]. Furthermore, the beer market has continued to grow on a global scale, even in countries where alcoholic beverages are not traditional $[25,26]$. With eyes on the future, it seems that the beer industry is gaining economic importance [25, 27, 28]. Fueled by the recently generated health concern among the scientific and public communities, the presence of unwanted concerning metal contaminants in beer could prove to be the decisive factor in the projected market race $[29,30]$.

Unfortunately, the existing regulatory policy does not appear congruous with the potential hazards and future economic trends. There are no regulations, for example, that impose maximum concerning metal concentration limits for beers entering the US market. Furthermore, there are also no well-established monitoring policies, which could serve as a basis for framing such regulations in the future. The Department of Treasury, which regulates the manufacture and trade of beer in the US, requires that water with potable quality be used for the production of beer [31]. This definition, however, is very vague and exhibits significant flaws because: (1) potable water quality defections are country specific; and (2) it does not clearly define whether the final beer product should comply with the US water quality regulations. To illustrate this, arsenic, which is commonly found in potable water and in beer manufacturing ingredients, is regulated by the US EPA with an MCL of $10 \mu \mathrm{g} / \mathrm{l}$. The same MCL value is also promulgated by Canada and the European Union [32]. Considering a different techno-economic criterion, Australia has promul- 
gated a lower arsenic standard of $7 \mu \mathrm{g} / 1$ [32]. In contrast, however, many countries that export beer to the US have promulgated arsenic MCLs of 50 $\mu \mathrm{g} / 1$ [32]. In light of these regulatory differences and the vague US Department of Treasury definition, it becomes necessary to better understand the existing concerning metal content trends in beers entering the US market, and especially the beers imported from developing countries. The underlying questions of this study are: (1) how do the concerning metal concentrations of beers imported to the US marked compare to those in US produced beers; and (2) do imported and domestic beers exhibit concerning metal concentrations below the existing US primary drinking water standards? The underlying question of importance is framed around the need to inform the US consumers about the potential health hazards originating from the regulatory deficiencies and inadequate capacity to conduct the complete screening of beverage products entering the US. To address the goal of this study: (1) beers manufactured worldwide, which are commercially available on the US market were obtained; (2) the concentration of concerning metals in the beers was analyzed; and (3) data were examined and correlated to explore any US MCL exceedances and determine whether geographic or grain-related trends exist.

\section{EXPERIMENTAL APPROACH}

\subsection{Beers selection and geographic distribution}

A set of 82 domestic and imported beers from 33 countries across the world were purchased in commercial liquor establishments located in Arizona, USA. This set included 77 beers with different commercial names and 5 duplicates. The geographic distribution of the breweries where the beers were produced is illustrated in Figure 1. Grain type used for beer production was obtained from the manufacturer's specifications and included barley, wheat, rice, and oatmeal.

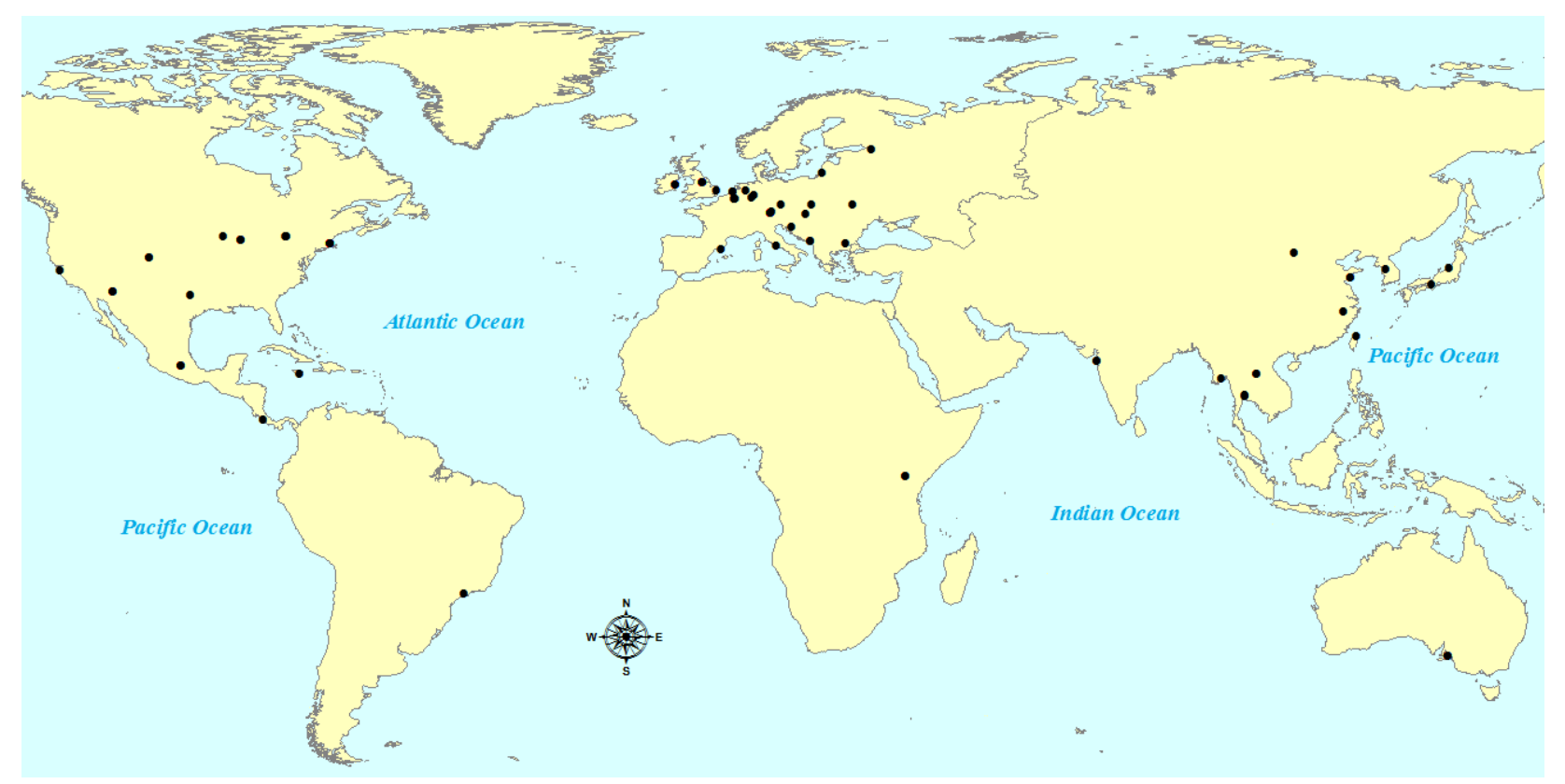

Fig. 1. Geographical distribution of factories where the examined beers were brewed

\subsection{Sample preparation and analysis of concerning metal concentrations}

Sample aliquots from each beer were obtained immediately after opening the beers and pouring $50 \mathrm{ml}$ into a $60 \mathrm{ml}$ teflon septa vial precleared by sonication in $10 \%$ nitric acid bath and triple-rinsed with ultrapure water $(18.2 \mathrm{M} \Omega / \mathrm{cm})$. The samples were preserved with ultra-trace analysis grade nitric acid and stored at $4{ }^{\circ} \mathrm{C}$ before di- gestion to eliminate the effects of the organic compounds (e.g. surfactants) found in this complex aqueous matrix.

Digestion was conducted by following the modified EPA method 3050B [33]. Specifically, digestion was conducted by preparing a $12.5 \mathrm{ml}$ aliquot from each preserved sample and mixing it with $3 \mathrm{ml}$ of concentrated $(\geq 67 \%)$ nitric acid and $1 \mathrm{ml}$ of hydrogen peroxide $(\geq 30 \%)$. Both the nitric acid and peroxide were ultra-trace grade. The 
mixtures were heated on a regulated hotplate at $100{ }^{\circ} \mathrm{C}$ until the solution was completely clear [34, 35]. The sample was cooled to room temperature before being diluted to $25 \mathrm{ml}$ with ultrapure water.

All samples were analyzed via inductively coupled plasma optical emission spectroscopy (ICP-OES, Thermo iCAP6300 Radial) using 22 multi-element standards (Al, Ag, As, Ba, Be, Bi, $\mathrm{Cd}, \mathrm{Co}, \mathrm{Cr}, \mathrm{Cu}, \mathrm{Fe}, \mathrm{Li}, \mathrm{Mn}, \mathrm{Mo}, \mathrm{Ni}, \mathrm{Pb}, \mathrm{Sb}, \mathrm{Se}, \mathrm{Sr}$, $\mathrm{Tl}, \mathrm{V}$, and $\mathrm{Zn}$ ). For the elements where the minimum detection limit was low, the standard additions method was employed, and the concentration of the target analyte was selectively increased by spiking a known analyte mass into the sample. Increasing the concentration of target analytes above the noise level resulted in improved sensitivity [36, 37]. In this study, the concentration of $\mathrm{As}, \mathrm{Ag}, \mathrm{Cr}$, $\mathrm{Pb}, \mathrm{Sb}$ and $\mathrm{Se}$ was determined via the standard additions method by spiking $50 \mu \mathrm{g} / \mathrm{l}$ of the targeted analyte.

Commercially available multi-element calibration standard (LGC) was used to prepare calibration curves in the $10-500 \mu \mathrm{g} / 1$ concentration range with correlation coefficient $\mathrm{R}^{2}>0.995$ for all analyzed elements. Quality control sample was analyzed every 10 samples and all mean recoveries were within $+/-10 \%$ of the expected value. Each sample was analyzed in an analytical triplicate and the concentration of elements was measured on two wavelengths. Table S1 summarizes the wavelengths used in ICP-OES measurements of all 22 metals.

\subsection{Statistical data analysis}

To better understand the different hazard levels, the detected metal concentrations were divided into the three groups. The first group addresses the enforceable national primary drinking water standards (NPDWS) which apply to public water systems and aim to protect the public [38]. The second group addresses the non-enforceable secondary water quality standards (NSDWS), which aim to establish guidelines for aesthetics considerations [38]. However, many state health agencies and public water systems in the US frequently monitor and treat their supplies for secondary contaminants. The presence of these nonenforceable metal contaminants enabled the overall water quality matrix in beer to be better understood. The third group addresses the contaminants encompassed by the Third Unregulated Contaminant Monitoring Rule (UCMR 3), which provides a basis for future regulatory actions to protect public health [38]. Contaminants subject to UCMR3 were included in the contaminant candidate list (CCL3). This list contains contaminants that are known or anticipated to occur in public water systems, and are not currently regulated, but might be regulated in the future.

To assess whether any correlating trends between the geographical origin and ingredients of the examined beers exist with regard to the presence of concerning metals, the concentrations of metals were correlated with: (1) regions and countries of brewery factories; and (2) grain types used in the manufacture of beers. Only the elements which exceeded the regulatory or guideline limits in at least one beer were considered in geographical and ingredient correlations. The comparison of beers in each of the selected groups was based on the average concentration of metals and its deviation. Non-detected metals were included as zero values in the calculation. To simplify the visual comparison between the samples and illustrate the average metal concentration in each beer group, column bar graphs were used. The column bars were accompanied by appropriate error limits to indicate whether statistically significant differences exist. Depending on the number of samples $(n)$ encompassed by each beer group, error bars representing the $95 \%$ confidence interval (CI) for $n \geq 3$ or minimum and maximum values for $n=2$ were presented. The data related to the beer originating from South America have no error bars because only one sample was examined $(n=1)$. When $n \geq$ 3 , the $95 \%$ confidence intervals were used to describe the $95 \%$ probability range of the concentration for specific metals in the selected beer categories.

\section{RESULTS AND DISCUSSION}

\subsection{Identification of drinking water regulated concerning metal contaminants}

Figure 2 illustrates the average metal concentrations detected in the beer samples as compared to the US EPA national primary and secondary drinking water standards and the unregulated contaminants that require monitoring and belong to the contaminant candidate list 3 . Information about the concentration range of metals and the corresponding average are summarized in Table S2 of Supplement Information. 

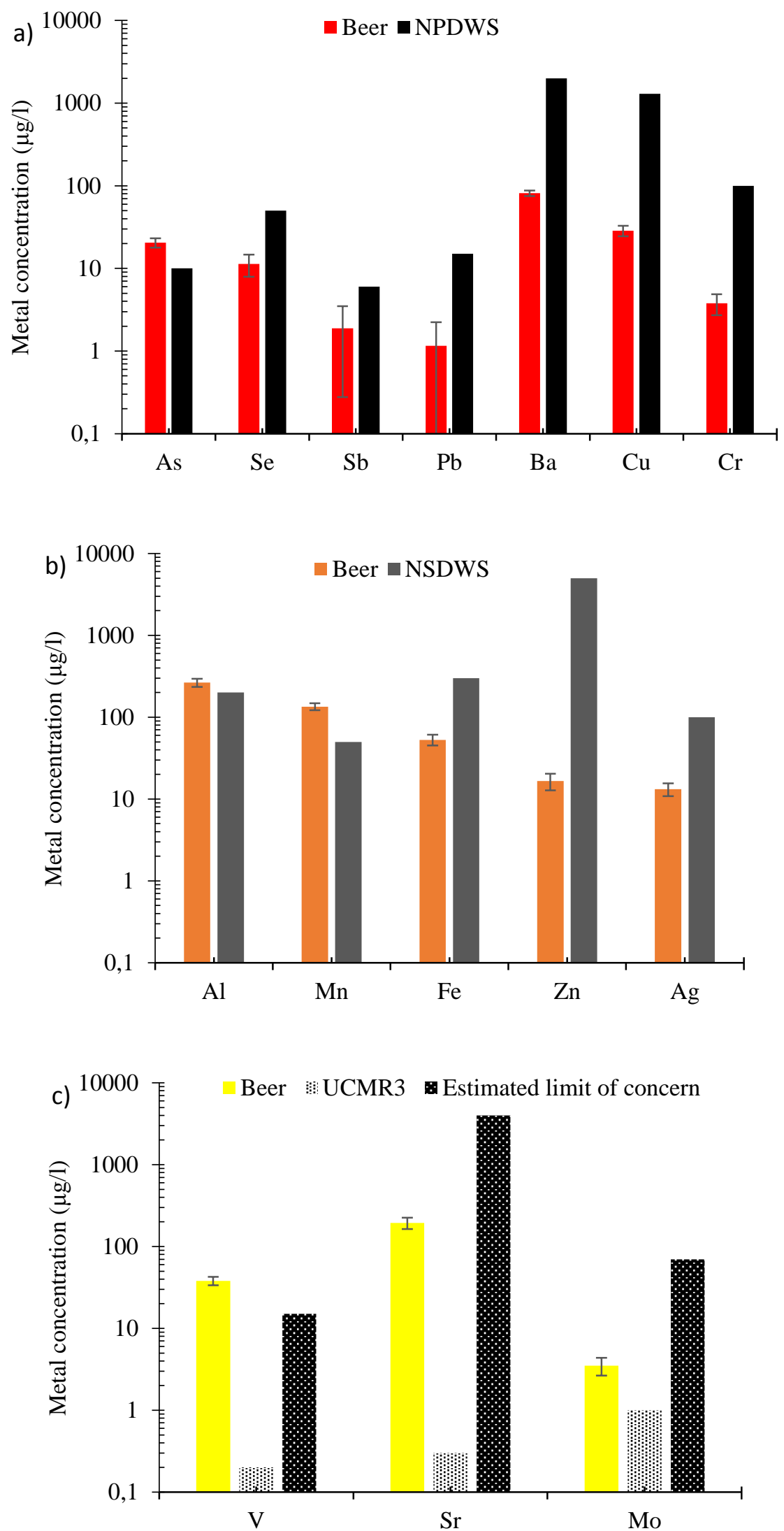

Fig. 2. Average concentration of metals in beers $(n=82)$ in comparison to corresponding MCL defined by (a) national primary drinking water standard (NPDWS) and (b) national secondary drinking water standard (NSDWS), or requirement for monitoring by (c) UCMR3 and proposed to be regulated by contaminant candidate list (CCL3). Error bars represent $95 \%$ confidence interval. 


\subsubsection{Metals with national primary drinking water standards found in beer}

Figure 2a summarizes the seven elements that were detected and have established MCL values under the NPDWS. Interestingly, all concerning metal contaminants exhibited average concentrations below the corresponding MCL values except for arsenic. Arsenic was detected in $76 \%$ of the samples, with an average arsenic concentration of $21 \pm 2.7(\mathrm{CI}) \mu \mathrm{g} / \mathrm{l}$, which was two times greater than the MCL for arsenic. Over two thirds of the samples $(68 \%)$ contained arsenic in excess of the US EPA regulated $10 \mu \mathrm{g} / \mathrm{l}$ limit, with the highest detected value of $63 \mu \mathrm{g} / \mathrm{l}$, which is over six times the regulatory limit. These arsenic values correspond well with a recent study by Rodrigo et al. [39], which included 125 beers retailing in the UK market and reported an average arsenic concentration of $63 \mu \mathrm{g} / \mathrm{l}$. Such high arsenic concentrations could be attributed to contributions from a filtration process that employs diatomaceous earth, as reported by studies conducted by the Weihenstephan research center [40]. In the absence of actual reports to better understand how the beer production processes may contribute to arsenic and other concerning metal contaminants, it is imperative to expand the future research and prevent potential health risks like the one reported by Reynolds [41], who documented the 1900 Manchester arsenic-inbeer epidemic.

In addition to arsenic, the other contaminants in Figure 2a did not exceed the MCL contaminants, with the exception of a very small number of samples. Selenium, a potential cause of circulatory problems, was found in $38 \%$ of beers with an average concentration of $11 \pm 3.4(\mathrm{CI}) \mu \mathrm{g} / \mathrm{l}$. Only one sample $(1 \%)$ exceeded the selenium MCL, with $120 \mu \mathrm{g} / \mathrm{l}$, which was more than twice than the MCL value of $50 \mu \mathrm{g} / \mathrm{l}$ and could be considered a statistically negligible fraction. Unlike arsenic, selenium is rarely tested in beers. Rodrigo et al. [42], however, reported a wide selenium occurrence with the mean value of $25 \mu \mathrm{g} / \mathrm{l}$, which was about 2 times greater than the one observed in this study.

Antimony was much less prevalent in the analyzed beer samples. It was detected only in $6 \%$ of the samples with an average concentration $2 \pm$ $1.6(\mathrm{CI}) \mu \mathrm{g} / 1,5 \%$ of which exceeded MCL of 6 $\mu \mathrm{g} / \mathrm{l}$. The maximum detected concentration of antimony in this study was $84 \mu \mathrm{g} / \mathrm{l}$, which was a more than 10 times greater concentration than the MCL. This is interesting because antimony concentrations of $>10 \mu \mathrm{g} / 1$ have not been reported [43,
44]. Considering that the potential health effects of antimony include an increase in blood cholesterol and blood pressure and a decrease in blood sugar, and that its presence in food has already been documented [38, 45, 46], the occurrence of antimony in beers is not unexpected. However, the scarce number of reports that exist suggests that the presence of antimony in beverages has not been sufficiently explored.

Similar to antimony, lead was found in $4 \%$ of beers with an average concentration of $1.1 \pm$ 1.1(CI) $\mu \mathrm{g} / \mathrm{l}$. Two thirds of the lead-positive samples exceeded the MCL of $15 \mu \mathrm{g} / \mathrm{l}$, with the highest detected value of $48 \mu \mathrm{g} / \mathrm{l}$. Previous reports, however, documented that lead could even occur at higher concentrations $\geq 24 \mu \mathrm{g} / \mathrm{l}$ in beers found on the Spanish market [47]. High lead concentrations have the potential to cause kidney problems and high blood pressure in adults [38, 48, 49].

In contrast to arsenic, antimony, selenium and lead, the other NPDWS regulated metals exhibited concentrations that were significantly lower than the enforceable MCLs. The highest barium concentration detected in the beer samples was 192 $\mu \mathrm{g} / \mathrm{l}$, which was more than 10 times lower than the MCL of $2000 \mu \mathrm{g} / \mathrm{l}$. Similarly, copper was found in $73 \%$ of the samples, with a maximal concentration of $138 \mu \mathrm{g} / \mathrm{l}$, which is almost an order of magnitude lower than the regulated MCL of $1300 \mu \mathrm{g} / \mathrm{l}$. Copper in a similar range (from 29 to $150 \mu \mathrm{g} / \mathrm{l}$ ) also was found in all Polish beers [50]. Interestingly, however, Ibanez et al. [18] reported extremely high concentrations of copper in some beers, of 58,000 $\mu \mathrm{g} / \mathrm{l}$. Chromium concentrations were also significantly lower than the NPDWS MCL for total chromium of $100 \mu \mathrm{g} / \mathrm{l}$. Chromium was detected in about $30 \%$ of beers, with the highest concentration measured at $37 \mu \mathrm{g} / \mathrm{l}$. These results correspond to findings from other studies, where the maximal chromium concentrations of $33 \mu \mathrm{g} / \mathrm{l}$ and $45 \mu \mathrm{g} / \mathrm{l}$ were reported for beers sold in the Canary Islands in Spain and Poland, respectively [19, 50].

\subsubsection{Metals with secondary drinking water standards found in beer}

Figure $2 \mathrm{~b}$ summarizes the findings for metals that are identified as agents which could contribute to the impaired taste and odor of water. They are non-enforceable standards in the US, although some countries (for example India) have classified some of these contaminants as enforceable [51].

Aluminum was found in $79 \%$ of examined beers. The average aluminum concentration in beer 
was $264 \pm 29.4(\mathrm{CI}) \mu \mathrm{g} / \mathrm{l}$, while the highest concentration was about $690 \mu \mathrm{g} / \mathrm{l}$ (Fig. 2b). Aluminum concentrations that were greater than the US EPA promulgated secondary MCL (SMCL) of $200 \mu \mathrm{g} / 1$ were found in $61 \%$ of beers. Similar ranges for aluminum concentration in beer were found by Szefer and Nriagu [52] and Lopez et al. [53], who reported the highest values of about 600 and 790 $\mu \mathrm{g} / \mathrm{l}$, respectively. Although the detected aluminum concentrations were significantly greater than the SMCL, such relatively high concentrations of aluminum should not be regarded as a health risk. Nonetheless, older reports link high aluminum concentrations to factors contributing associated with the onset of Alzheimer's disease, encephalopathies and in some cases, osteomalacia [54, 55].

Manganese was also found in relatively high concentrations in the majority of beer samples. It was detected in about $95 \%$ of the examined beers. The average manganese concentration was $135 \pm$ 13.4(CI) $\mu \mathrm{g} / \mathrm{l}$. Manganese in the range 340-390 $\mu \mathrm{g} / \mathrm{l}$ was detected in four beer samples, which is 7 8 times greater than the corresponding SMCL for manganese of $50 \mu \mathrm{g} / \mathrm{l}$. Interestingly, about $90 \%$ of the samples exhibited manganese concentrations in excess of the SMCL. These findings are not dissimilar to those reported by previous studies, which suggest that the high presence of manganese in beer deserves close monitoring because of its potential neurological toxicity [39, 50, 56, 57].

Although extensively present in beer, the concentrations of iron and zinc did not exceed the SMCL of $300 \mu \mathrm{g} / 1$ and $5000 \mu \mathrm{g} / 1$, respectively. Iron was detected in $90 \%$ of the beer samples with an average concentration of $53 \pm 7.9(\mathrm{CI}) \mu \mathrm{g} / \mathrm{l}$ and a maximum detected concentration of $308 \mu \mathrm{g} / \mathrm{l}$. Zinc was detected in $80 \%$ of beers with the average concentration of $17 \pm 3.8(\mathrm{CI}) \mu \mathrm{g} / \mathrm{l}$ and the highest concentration of $137 \mu \mathrm{g} / \mathrm{l}$. A similar range of concentrations for both iron and zinc was detected in Polish beers, ranging between 45 and $530 \mu \mathrm{g} / \mathrm{l}$ for iron and between 4 and $120 \mu \mathrm{g} / 1$ for zinc [50]. The presence of iron and zinc in beer is typically attributed to the corrosion of process equipment; however, contributions from beer manufacturing ingredients should not be excluded [58, 59].

Silver was found in $55 \%$ of the beer samples with an average concentration of $13 \pm 2.3(\mathrm{CI})$ $\mu \mathrm{g} / \mathrm{l}$ and a maximum of $53 \mu \mathrm{g} / \mathrm{l}$. These concentrations are significantly lower than the silver SMCL of $100 \mu \mathrm{g} / \mathrm{l}$. Such low concentrations of silver are not uncommon for potable water. Specifically, it has been found that between $10 \%$ and $33 \%$ of drinking water across the US contains silver in the concentrations ranging from $30 \mu \mathrm{g} / \mathrm{l}$ to $80 \mu \mathrm{g} / \mathrm{l}$ [60].

\subsubsection{Metals from Contaminant Candidate List 3 (CCL3) found in beer}

Figure 2c summarizes the detected metals in the beer samples that are on the CCL3 list. Vanadium was the only metal from this group of unregulated elements with an average concentration of $38 \pm 4.5(\mathrm{CI}) \mu \mathrm{g} / \mathrm{l}$, exceeding the levels promulgated by UCMR3 of $0.2 \mu \mathrm{g} / \mathrm{l}$. According to the US Agency for Toxic Substances and Disease Registry (ATSDR), these values also exceeded the level of health concern $(15 \mu \mathrm{g} / \mathrm{l})$ [61, 38]. Surprisingly, vanadium was found in $73 \%$ of the beer samples with maximum concentrations of about $117 \mu \mathrm{g} / \mathrm{l}$. Similar findings have been previously reported by Wuilloud et al. [62] and Minoia et al. [63] who detected vanadium concentrations in beer to of 200 $\mu \mathrm{g} / \mathrm{l}$. Such high vanadium concentrations could be considered a potential health risk considering that vanadium pentoxide is in group 2B (possibly carcinogenic to humans) and this element is under consideration of becoming a regulated contaminant [64]. The origin of vanadium in beer is unclear and not well studied; however, it is interesting to note that vanadium has a similar chemistry to arsenic and may have similar plant transport and accumulation mechanisms [65]. Furthermore, it is typically present in waters with high arsenic concentrations, so these two routes could be the dominant sources of vanadium in beer.

Strontium and molybdenum were detected in $91 \%$ and $37 \%$ of beer samples with the average concentrations of $195 \pm 31.2(\mathrm{CI}) \mu \mathrm{g} / \mathrm{l}$ and $4 \pm$ $0.9(\mathrm{CI}) \mu \mathrm{g} / \mathrm{l}$, respectively. According to UCMR3, both concerning metals require reporting because they exceed their respective limits of $3 \mu \mathrm{g} / \mathrm{l}$ for strontium and $1 \mu \mathrm{g} / \mathrm{l}$ for molybdenum. However, no beer samples exceeded strontium and molybdenum levels of concern according to ATSDR guidelines.

\subsection{The impact of geographic origin of beers on the presence of concerning metals}

Figure 3 illustrates the concentration of detected NPDWS metals in beers with respect to their regional and country origins. Table S3 of the Supplementary Information additionally summarizes metal concentration ranges and the corresponding average for each geographical group. 

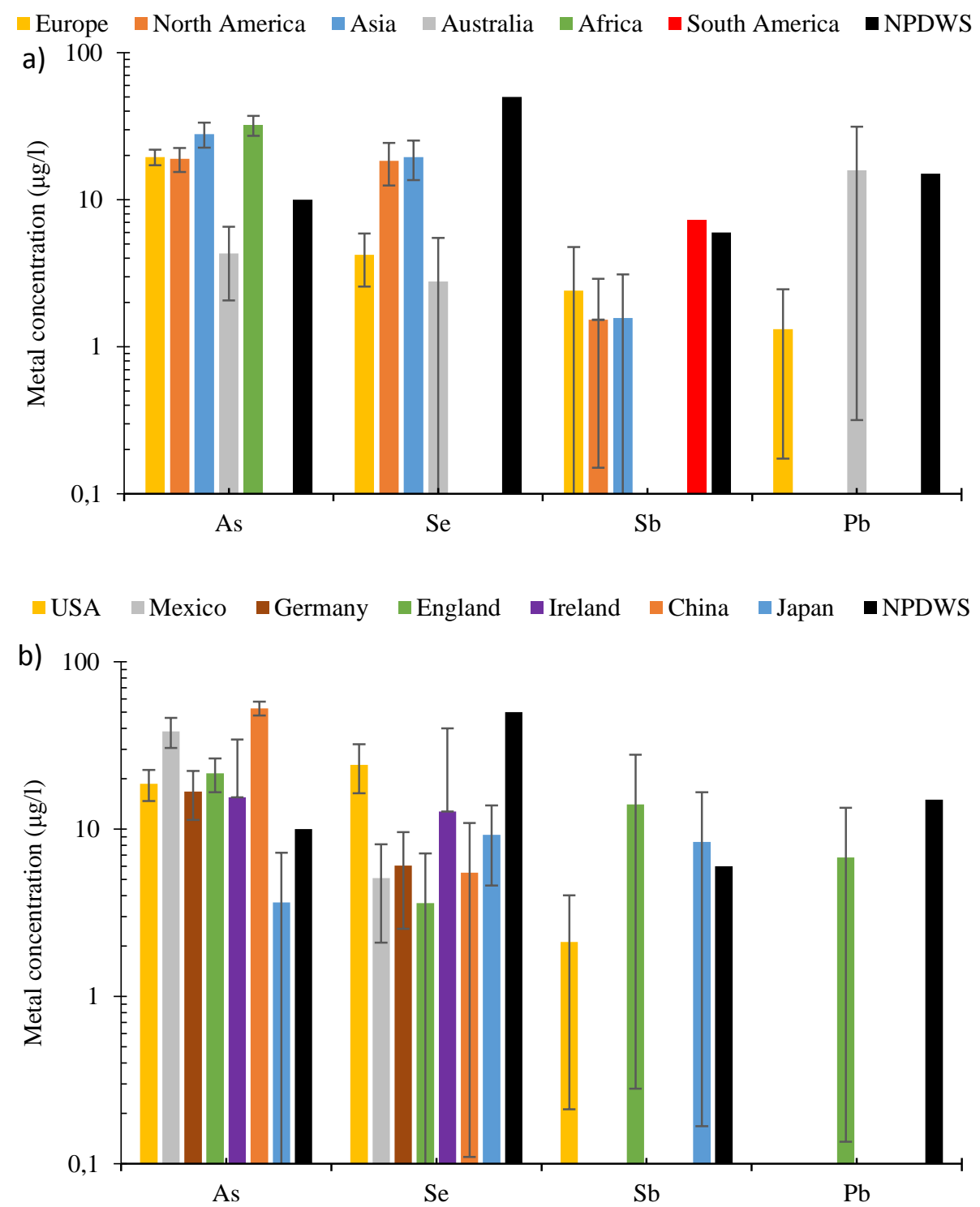

Fig. 3. Average concentration of metals regarding the (a) continent and (b) country of beers origin in comparison to corresponding MCL defined by national primary drinking water standards (NPDWS): Europe $(n=35)$, North America $(n=25)$, Asia $(n=16)$, Australia $(n=3)$, Africa $(n=2)$, South America $(n=1)$; US $(n=18)$, Mexico $(n=3)$, Germany $(n=9)$, England $(n=6)$, Ireland $(n=3)$, China $(n=4)$, Japan $(n=3)$. Error bars represent $95 \%$ confidence interval for $n \geq 3$ and minimum and maximum values for $n=2$. For Ireland beer group half of the error bar is higher than the average As or Se concentration.

With the exception of Australia, the average concentrations of all beers from the other world regions exhibited arsenic concentrations above the $10 \mu \mathrm{g} / 1$ US NPDWS MCLs. Beers from Asia and Africa had slightly higher concentrations of arsenic than the North American and European beers. It appears that Chinese and Mexican beer samples, which had higher arsenic concentrations, contributed the most to this trend. These beer samples had higher average arsenic concentrations than the European and American beer samples. Interestingly, Japanese beers exhibited arsenic concentrations that were lower than the NPDWS MCLs. In contrast, South American beers did not show the pres- ence of arsenic, although these findings should be taken with a caveat considering that a very limited number of beers from this region were examined. One South American beer, however, exhibited an antimony concentration that was greater than the NPDWS MCL. Although the average regional concentrations of antimony did not exceed the NPDWS MCL, some English and Japanese beer samples contained antimony that exceeded the standard limit. Interestingly, some English and Australian beer samples contained high lead concentrations. However, the $95 \%$ confidence limit bars indicated great variability in lead concentrations because of the small number of samples ana- 
lyzed, so these findings should be interpreted as potential indicators of lead being a contaminant of interest in English and Australian beers. The average selenium concentrations were below the NPDWS MCL, with limited variability, as illustrated by small error bars. The US beers had the highest selenium concentrations together with the Irish beers. This is in line with Rodrigo et al. [42], who reported that selenium concentrations were the highest in the US beers when compared to beers from 10 other countries.

Figure 4 illustrates the concentrations of aluminum, manganese and vanadium in beers with respect to their regional and country origins. Concentration ranges and the corresponding average of these metals for each geographical group are summarized in Table S3.

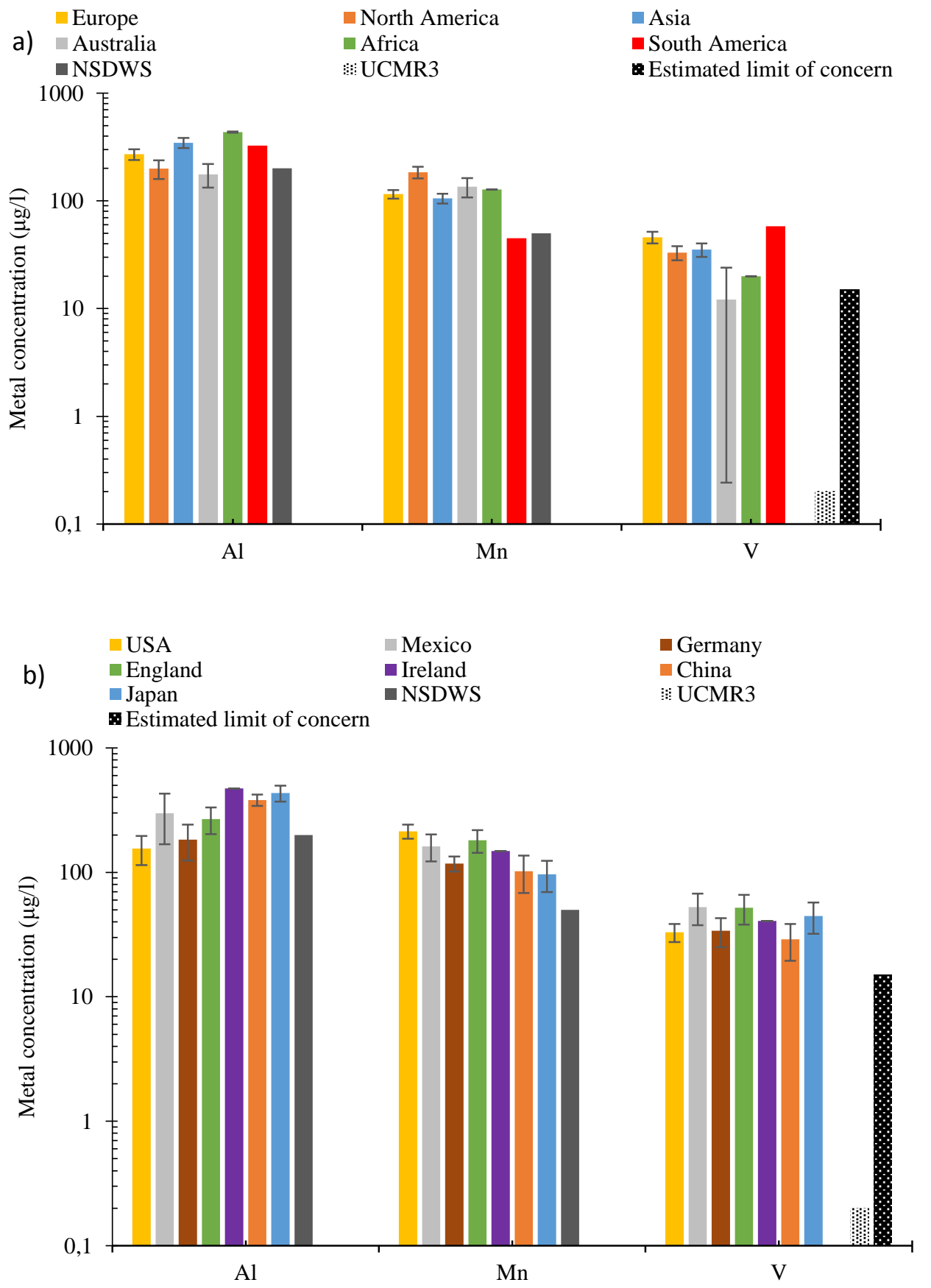

Fig. 4. Average concentration of metals regarding the (a) continent and (b) country of beers origin in comparison to corresponding MCL defined by national secondary drinking water standards (NSDWS) or requirement for monitoring (UCMR3): Europe $(n=35)$, North America $(n=25)$, Asia $(n=16)$, Australia $(n=3)$, Africa $(n=2)$, South America $(n=1)$; US $(n=18)$, Mexico $(n=3)$, Germany $(n=9)$, England $(n=6)$, Ireland $(n=3)$, China $(n=4)$, Japan $(n=3)$. Error bars represent $95 \%$ confidence interval for $n \geq 3$ and minimum and maximum values for $n=2$. 
Except for Australian beers, the average aluminum concentrations exceeded SMCL in all beer samples regardless of the beer's origin. Although the average aluminum concentration in Australian beers was lower than the SMCL, some samples exceeded the guideline limits, as indicated by a $95 \%$ confidence limit bar. Manganese exhibited the same trend of exceeding the SMCL, regardless of the region, except for one beer from the South American continent. Regardless of the region or country of origin, all beers exceeded the vanadium UMCR3 limit and the estimated ATSDR limits of concern. Interestingly, some Australian beers had vanadium concentrations that were lower than the estimated limit of concern. These trends coincide well with the arsenic trend. Such coincidences are not surprising considering that arsenic and vanadium have similar oxyanion chemistry [66].

\subsection{Impact of grains used in beer production on contaminant occurrence}

Figure 5 compares the concentration of concerning metal with respect to the grain ingredients used in the brewing process. Information about the metal concentration range and corresponding average for each grain group is summarized in Table S3 of the Supplementary Information.

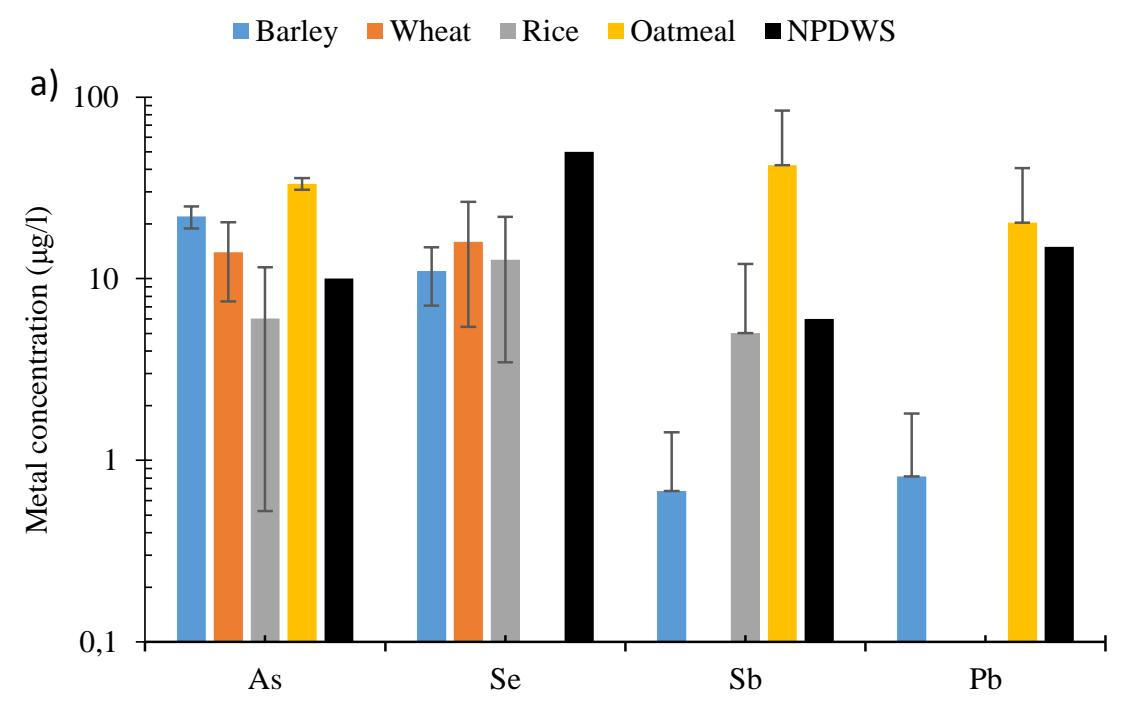

$\square$ Barley $\square$ Wheat $\square$ Rice $\square$ Oatmeal $\square$ NSDWS : : UCMR3 Estimated limit of concern

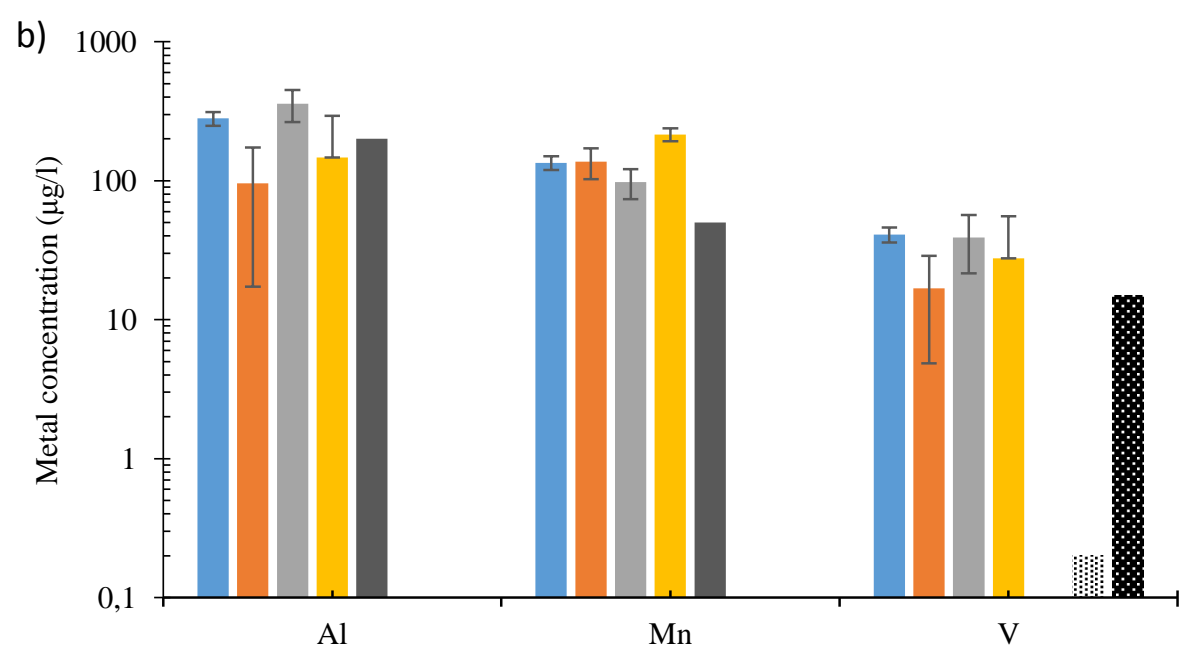

Fig. 5. Average concentration of metals regarding grains used in beers manufacturing: barley $(n=67)$, wheat $(n=8)$, rice $(n=5)$, oatmeal $(n=2)$ in comparison to corresponding MCL defined by (a) national primary drinking water standards (NPDWS) and (b) national secondary drinking water standards (NSDWS) or requirement for monitoring (UCMR3). Error bars represent $95 \%$ confidence interval for $n \geq 3$ and minimum and maximum values for $n=2$. For some beer groups half of the error bar is higher than the average $\mathrm{Sb}, \mathrm{Pb}, \mathrm{Al}$ or $\mathrm{V}$ concentration. 
Although the rice beer was expected to exhibit the highest arsenic concentrations because of the recent findings that arsenic is bio-accumulated by rice, the average concentration of arsenic in the tested rice beers was below the NPDWS MCL and the lowest compared to the other types of beer [23, 67-69]. Oatmeal and barley beers exhibited the highest concentrations of arsenic; however, the oatmeal beer data have to be considered with caution because only two oatmeal beers were examined. Similar caveats have to be considered for antimony and lead with respect to the oatmeal beer. The data suggest that oatmeal may contribute to elevated lead and antimony concentrations in beer. This has to be further investigated; however, in the absence of any data, this single data point represents a starting point that could lead to future inquiries. In contrast, selenium was not detected in the oatmeal beer. The concentration of selenium was statistically the same for all of the examined beers, and was below the NPDWS MCL.

Wheat and oatmeal beers exhibited the lowest average concentration of aluminum, which was lower than the SMCL. In contrast, barley and rice beers had greater aluminum concentrations than the SMCL. Manganese, however, was present in all types of beer above the SMCL. As reported by Porter and Bamforth [56], manganese is present in grains at high levels, and its leaching from the grains into beer is more significant than iron. This could be attributed to manganese chemistry, however, no studies exist to confirm this hypothesis.

Vanadium concentrations in the different beer types were similar and exceeded the UCMR3 and the ATSDRs limit of concern. Although abundant in soil, vanadium exhibited very low concentrations of about $1 \mu \mathrm{g} / 1$ in tap water samples collected across the US. In contrast, food analysis studies documented that grains could contain up to $105 \mathrm{mg} / \mathrm{kg}$ of vanadium, which designated them as a one of major routes of vanadium exposure for the general population [60]. Based on these findings, it seems that manganese and vanadium found in beers originate mainly from grains, but the results obtained in this study could not determine whether they are grain specific or not. Rather than being environmentally conditioned (water and grains), aluminum occurrence, on the other hand, probably results from beer manufacturing steps (e.g. equipment or additives) or bottling [18, 53, 70].

\section{CONCLUSIONS}

In light of the data generated from this study, it is evident that specific heavy metals, like arsenic, are present in beers in concentrations that exceed the NPDWS MCLs. In general, there are no significant differences between the concerning metals' concentrations of imported and domestic beers on the US market. Although water quality may be a factor contributing to the elevated concentrations of concerning metals in beers, it is more likely that the grain ingredients are greater contributors to these trends. The brewing processes could also contribute to the introduction of some of these evaluated metals in beer. However, to adequately address the exposure concerns, the regulatory deficiencies have to be addressed together with increasing the requirements for monitoring the quality of imported and domestic beverages.

Acknowledgements. The authors express their gratitude to Mr. Dragoslav N. Hristovski for his contributions during the beer sampling process.

\section{REFERENCES}

[1] C. F. Chau, S. H. Wu, G. C. Yen, The development of regulations for food nanotechnology, Trends Food Sci. Technol. 18, 269-280 (2007). DOI: https://doi.org/10.1016/j.tifs.2007.01.007

[2] R. Skaggs, C. Falk, J. Almonte, M. Cdrdenas, ProductCountry Images and International Food Marketing: Relationships and Research Needs, Agribusiness 12(6), 593-600 (1996).

DOI: https://doi.org/10.1002/(SICI)1520-6297(199611/12) 12:6<593::AID-AGR8>3.0.CO;2-Z

[3] T. A. Hemphill, Globalization of the U.S. Food supply: reconciling product safety regulation with free trade, Bus. Econ. 44(3), 154-168 (2009). DOI: https://doi.org/10.1057/be.2009.18

[4] US Food \& Drug Administration (FDA), Mercury Levels in Commercial Fish and Shellfish (1990-2012), 2017, Cited 2018 July 06. Available from: https://www.fda.gov/food/foodborneillnesscontaminants /metals/ucm115644.htm

[5] J. S. Jothi, M. B. Uddin, Detection of heavy metals in some commercial brands of noodles, Eur. Acad. Res. 2(8), 10667-10679 (2014).

[6] N. A. Al-Dhabi, Heavy metal analysis in commercial Spirulina products for human consumption, Saudi J. Biol. Sci., 20, 383-388 (2013).

DOI: https://doi.org/10.1016/j.sjbs.2013.04.006

[7] New earth, More than half of baby food products contaminated with toxic heavy metals, 2017, Cited 2018 July 06 . Available from: https://newearth.media/half-babyfood-products-contaminated-toxic-heavy-metals/

[8] D. Wilson, C. Hooper, X. Shi, Arsenic and lead in juice: apple, citrus and apple-base, J. Environ. Health, 75(5) 14-21 (2012).

[9] J. Roberge, A. T. Abalos, J. M. Skinner, M. Kopplin, R. B. Harris, Presence of arsenic in commercial beverages, Am. J. Environ. Sci. 5(6), 688-694 (2009). 
[10] T. Hague, A. Petroczi, P. L. R. Andrews, J. Barker, D. P. Naughton, Determination of metal ion content of beverages and estimation of target hazard quotients: a comparative study, Chem. Cent. J. 2(13), 1-9 (2008). DOI: $10.1186 / 1752-153 X-2-13$

[11] S. S. Al-Oud, Heavy metal contents in tea and herb leaves, Pak. J. Bio. Sci. 6(3), 208-2012 (2003).

[12] C. M. A. Iwegbue, S. O. Nwozo, E. K. Ossai, G. E. Nwajei, Heavy metal composition of some imported canned fruit drinks in Nigeria, Am. J. Food Technol. 3, 220-223 (2008). DOI: 10.3923/ajft.2008.220.223

[13] D. Thompson, How America Drinks: Water and Wine Surge, Cheap Beer and Soda Crash, 2013, Cited 2018 July 06. Available from: https://www.theatlantic.com/business/archive/2013/01/how-america-drinks-water-andwine- surge-cheap-beer-and-soda-crash/267153/

[14] J. C. Barefoot, M. Grønbæk, J. R Feaganes, R. S. McPherson, R. B. Williams, I. C Siegler, Alcoholic beverage preference, diet, and health habits in the UNC Alumni Heart Study, Am. J. Clin. Nutr. 76(2), 466-472 (2002).

[15] The Beer Institute, Brewers Almanac, Beer consumption by country, 2013. Cited 2018, April 11, Available from: https://web.archive.org/web/20130604022127/http://ww w.beerinstitute.org/assets/uploads/Brewers_Almanac_20131.xlsx

[16] Dietary Guideline for Americans 2015-2020, Appendix 9. Alcohol. Cited 2018 September 5. Available from: https://health.gov/dietaryguidelines/2015/guidelines/app endix-9/.

[17] G. Donadini, S. Spalla, G. M. Beone, Arsenic, cadmium and lead in beers from the Italian market, J. Inst. Brew., 114(4), 283-288 (2008).

DOI: https://doi.org/10.1002/j.2050-0416.2008.tb00770.x

[18] J. G. Ibanez, A. Carreon-Alvarez, M. Barcena-Soto, N. Casillas, Metals in alcoholic beverages: A review of sources, effects, concentrations, removal, speciation, and analysis, J. Food Compos. Anal., 21, 672- 683 (2008). DOI: https://doi.org/10.1016/j.jfca.2008.06.005

[19] D. González-Weller, C. Rubio, Á. J. Gutiérrez, G. L. González, J. M. C. Mesa, C. R. Gironés, A. B. Ojeda, A. Hardisson, Dietary intake of barium, bismuth, chromium, lithium, and strontium in a Spanish population $(\mathrm{Ca}-$ nary Islands, Spain), Food Chem. Toxicol., 62, 856-868 (2013). DOI: https://doi.org/10.1016/j.fct.2013.10.026

[20] B. V. Tangahu, S. R. S. Abdullah, H. Basri, M. Idris, N. Anuar, M. Mukhlisin, A Review on heavy metals (As, $\mathrm{Pb}$ and $\mathrm{Hg}$ ) uptake by plants through phytoremediation, Int. J. Chem. Eng., 2011, 1-31 (2011). DOI: http://dx.doi.org/10.1155/2011/939161

[21] C. LaCoste, B. Robinson, R. Brooks, Uptake of thallium by vegetables: Its significance for human health, phytoremediation, and phytomining, J. Plant Nutr., 24(8), 1205-1215 (2001). DOI: https://doi.org/10.1081/PLN-100106976

[22] V. Antoniadis, E. Levizou, S. M. Shaheen, Y. Sik Ok, A Sebastian, C. Baum, M. N. V. Prasad, W. W. Wenzel, J. Rinkleb, Trace elements in the soil-plant interface: Phytoavailability, translocation, and phytoremediation - A review, Earth-Sci. Rev. 171, 621-645 (2017). DOI:https://doi.org/10.1016/j.earscirev.2017.06.005

[23] US Food \& Drug Administration (FDA), Arsenic in Rice and Rice Products, 2016. Cited 2018 April 11, Available from:https://www.fda.gov/Food/FoodborneIllnessConta minants/Metals/ucm319870.htm

[24] Consumer Reports, FDA data show arsenic in rice, juice, and beer: Here's an overview of some significant developments regarding arsenic in food in the last year, 2014. Cited 2018 April 11. Available from: https://www.consumerreports.org/cro/news/2014/01/fda-data-show-arsenic-in-rice-juice-and-beer/index.htm

[25] T. Goldammer, The Brewer's Handbook A Complete Book to Brewing Beer, APEX Publisher, $2^{\text {nd }}$ Edition, 2008. Cited 2018 April 11. Available from: http://www.beerbrewing.com/beer_brewing/beer_brewin g_chapters/ch01_beer_industry.htm

[26] Ansamed, Islam: Survey, alcohol use in Mideast-Africa $+25 \%$ in 5 years, 2011. Cited 2018 April 11. Available from:

http://www.webcitation.org/query?url=http://www.ansam ed.info/en/news/ME.XEF93985.html\&date=2011-02-25

[27] The Beer Institute, Economic Impact, 2017. Cited 2018 July 06. Available from: http://www.beerinstitute.org/industryinsights/economic-impact/

[28] D. Richey, B. Watson, California Craft Brewing, Economic Impact Report, 2013. Cited 2018 July 06. Available from: http://www.californiacraftbeer.com/files/Economic-Impact-Study-FINAL.pdf

[29] M. Pigłowski, Heavy Metals in notifications of rapid alert system for food and feed, Int. J. Environ. Res. Public Health 15, 1-13 (2018). DOI: https://doi.org/10.3390/ijerph15020365

[30] C. Reilly, Metal Contamination of Food: Its Significance for Food Quality and Human Health, $3^{\text {rd }}$ edition, Blackwell Science Ltd, MA, USA, 2002.

[31] US Department of the Treasury, Beer Laws, Regulations, and Public Guidance, n.d. Cited 2018 April 11. Available from: https://www.ttb.gov/beer/beer-regs.shtml

[32] K. R. Henke, Arsenic: Environmental Chemistry, Health Threats and Waste Treatment, John Wiley \& Sons, Ltd., USA, 2009.

[33] US Environmental Protection Agency (US EPA), Method 3050B, Acid Digestion of sediments, sludges, and soils, 1996. Cited 2018 July 06. Available from: https://www.epa.gov/sites/production/files/201506/documents/epa-3050b.pdf

[34] C. M. A. Iwegbue, L. C. Overah, F. I. Bassey, B. S. Martincigh, Trace metal concentrations in distilled alcoholic beverages and liquors in Nigeria, J. Inst. Brew. 120, 521-528 (2014). DOI: https://doi.org/10.1002/jib.174

[35] A. Alcázar, F. Pablos, Ma. J. Martín, A. G. González, Multivariate characterization of beers according to their mineral content, Talanta, 57, 45-52 (2002). DOI: https://doi.org/10.1016/S0039-9140(01)00670-1

[36] S. T. Eshghi, X. Li, H. Zhang, Targeted Analyte Detection by Standard Addition Improves Detection Limits in 
MALDI Mass Spectrometry, Anal Chem., 84(18), 76267632 (2012). DOI: 10.1021/ac301423f

[37] A. Tyburska, K. Jankowski, A. Ramsza, E. Reszke, M. Strzelec, A. Andrzejczuk, Feasibility study of the determination of selenium, antimony and arsenic in drinking and mineral water by ICP-OES using a dual-flow ultrasonic nebulizer and direct hydride generation, J. Anal. At. Spectrom., 25, 210-214 (2010).

DOI: $10.1039 / \mathrm{B} 916729 \mathrm{C}$

[38] US Environmental Protection Agency (US EPA), Drinking Water Contaminants - Standards and Regulations, n.d. Cited 2018 July 06. Available from: https://www.epa.gov/dwstandardsregulations

[39] S. Rodrigo, S. D. Young, M. I. Talaverano, M. R. Broadley, The influence of style and origin on mineral composition of beers retailing in the UK, Eur. Food Res. Technol. 243, 931-939 (2017).

DOI: https://doi.org/10.1007/s00217-016-2805-y

[40] M. Coelhan, Widely used filtering material adds arsenic to beers, 245 th National Meeting \& Exposition of the American Chemical Society, New Orleans, 2013.

[41] E. S. Reynolds, An account of the epidemic outbreak of arsenical poisoning occurring in beer drinkers in the north of England and the midland counties in 1900, Lancet, 157(4038), 166-170 (1901).

[42] S. Rodrigo, S. D. Young, D. Cook, S. Wilkinson, S. Clegg, E. H. Bailey, A. W. Mathers, M. R. Broadley, Selenium in commercial beer and losses in the brewing process from wheat to beer, Food Chem., 182, 9-13 (2015). DOI: https://doi.org/10.1016/j.foodchem.2015.02.121

[43] H. Matusiewicz, M. Mikołajczak, Determination of As, $\mathrm{Sb}, \mathrm{Se}, \mathrm{Sn}$ and $\mathrm{Hg}$ in beer and wort by direct hydride generation sample introduction-electrothermal AAS, $J$. Anal. At. Spectrom., 16, 652-657 (2001).

DOI: $10.1039 / \mathrm{B} 100312 \mathrm{G}$

[44] N. Altunay, R. Gürkan, A new cloud point extraction procedure for determination of inorganic antimony species in beverages and biological samples by flame atomic absorption spectrometry, Food Chem., 175, 507-515 (2015).

DOI: https://doi.org/10.1016/j.foodchem.2014.12.012

[45] C. Hansen, A. Tsirigotaki, S. A. Bak, S. A. Pergantis, S. Stürup, B. Gammelgaard, H. R. Hansen, Elevated antimony concentrations in commercial juices, J. Environ. Monit., 12, 822-824 (2010). DOI: 10.1039/B926551A

[46] Agency for Toxic Substances and Disease Registry (ATSDR), Toxicological Profile for Antimony and Compounds, Draft for Public Comment, 2017. Cited 2018 July 06. Available from:

https://www.atsdr.cdc.gov/toxprofiles/tp23.pdf

[47] C. M. Mena, C. Cabrera, M. L. Lorenzo, M. C. Lopez, Determination of lead contamination in Spanish wines and other alcoholic beverages by flow injection atomic absorption spectrometry, J. Agric. Food Chem. 45(5), 1812-1815 (1997). DOI: 10.1021/jf960761e

[48] Agency for Toxic Substances and Disease Registry (ATSDR), Toxicological Profile for Lead, 2007. Cited 2018 July 06. Available from: https://www.atsdr.cdc.gov/toxprofiles/tp13.pdf, 2007
[49] N. C Papanikolaou, E. G. Hatzidaki, S. Belivanis, G. N. Tzanakakis, A. M Tsatsakis, Lead toxicity update. A brief review, Med. Sci. Monit. 11(10), 329-336 (2005).

[50] B. Wyrzykowska, K. Szymczyk, H. Ichichashi, J. Falandysz, B. Skwarzec, S. Yamasaki, Application of ICP sector field MS and principal component analysis for studying interdependences among 23 trace elements in Polish beers, J. Agric. Food Chem., 49, 3425-3431 (2001). DOI: $10.1021 / \mathrm{jf010184 \textrm {g }}$

[51] Bureau of Indian Standards (IS), Draft Indian Standard, Drinking Water Specification, Second Revision of IS 10500, ICS No. 13.060.20, Doc: FAD 25(2047)C, 2009.

[52] P. Szefer, J. O. Nriagu, Mineral Components in Foods, CRC Press, Boca Raton, FL, 2007.

[53] F. F. Lopez, C. Cabrera, M. L. Lorenzo, M. C. Lopez, Aluminium levels in wine, beer and other alcoholic beverages consumed in Spain, Sci. Total Environ., 220 1-9 (1998). DOI: https://doi.org/10.1016/S0048-9697(98)00214-9

[54] J. X. Liu, G. F. Nordberg, Nephrotoxicities of Aluminium and/or CadmiumMetallothionein in Rats: Creatinine Excretion and Metabolism of Selected Essential Metals, Pharmacol. Toxicol., 77, 155-160 (1995). DOI: https://doi.org/10.1111/j.1600-0773.1995.tb01005.x

[55] E. Storey, C. L. Masters, Amyloid, aluminium and the aetiology of Alzheimer's disease, Med. J. of Aust., 163, 256-259 (1995).

[56] J. R. Porter, C. W. Bamforth, Manganese in brewing raw materials, disposition during the brewing process and impact on the flavor instability of beer, J. Am. Soc. Brew. Chem., 74(2) (2016).

DOI: https://doi.org/10.1094/ASBCJ-2016-2638-01

[57] S. C. Izah, I. R. Inyang, T. C. N. Angaye, I. P. Okowa, A Review of heavy metal concentration and potential health implications of beverages consumed in Nigeria, Toxics, 5(1), 1-15 (2017). DOI:10.3390/toxics5010001

[58] E. Budman, R. R. Sizelove, Zinc alloy plating. Metal Finish., 98, 334-339 (2000).

[59] C. Reilly, Heavy metal contamination in home-produced beer and spirits, Ecol. Food Nutr., 2, 43- 47 (1973). DOI: https://doi.org/10.1080/03670244.1973.9990315

[60] Agency for Toxic Substances and Disease Registry (ATSDR), Public Health Statement for Silver. Atlanta, GA: U.S. Department of Health and Human Services, Public Health Service, 1900.

[61] Agency for Toxic Substances and Disease Registry (ATSDR), Public Health Statement. Toxicological profile for vanadium. (Draft for Public Comment). Atlanta, GA: U.S. Department of Health and Human Services, Public Health Service, 2009.

[62] R. Wuilloud, E. Marchevsky, R. Olsina, L. Martinez, Rapid and simple method for the determination of vanadium in beer by ICP AES with ultrasonic nebulization, J. Anal. Chem., 56, 77-80 (2001). DOI: https://doi.org/10.1023/A:1026779731251

[63] C. Minoia, E. Sabbioni, A. Ronchi, A. Gatti, R. Pietra, A. Nicolotti, S. Fortaner, C. Balducci, A. Fonte, C. Roggi, Trace element reference values in tissues from inhabitants of the European community. IV. Influence of die- 
tary factors, Sci. Total Environ., 141, 181-195 (1994). DOI: https://doi.org/10.1016/0048-9697(94)90027-2

[64] International Agency for Research on Cancer (IARC), Vanadium pentoxide: Possibly carcinogenic to humans, 2011. Cited 2018 April 11. Available from: https://www.atsdr.cdc.gov/substances/toxorganlisting.as $\mathrm{p}$ ?sysid $=74$

[65] T. Wällstedt; L. Björkvald; J. P. Gustafsson, Increasing concentrations of arsenic and vanadium in (southern) Swedish streams, Appl. Geochem. 25(8), 1162-1175 (2010). DOI: https://doi.org/10.1016/j.apgeochem.2010.05.002

[66] T. Burke, W. M. Mayes, C. L. Peacock, A. P. Brown, A. P. Jarvis, K. Gruiz, Speciation of arsenic, chromium, and vanadium in red mud samples from the Ajka Spill Site, Hungary, Environ. Sci. Technol. 46, 3085-3092 (2012). DOI: $10.1021 / \mathrm{es} 3003475$
[67] R. Tuli, D. Chakrabarty, P. K. Trivedi, R. D. Tripathi, Recent advances in arsenic accumulation and metabolism in rice, Mol. Breeding 26(2), 307-323 (2010). DOI: https://doi.org/10.1007/s11032-010-9412-6

[68] C. Potera, U. S. rice serves up arsenic, Environ. Health Persp. 115(6), 296-299 (2007).

[69] J.-H. Huang, K.-N. Hu, J. Ilgen, G. Ilgen, Occurrence and stability of inorganic and organic arsenic species in wines, rice wines and beers from Central European market, Food Additives \& Contaminants: Part A, 29(1), 8593 (2012).

DOI: https://doi.org/10.1080/19440049.2011.615029

[70] C. A. Blanco, D. Sancho, I. Caballero, Aluminium content in beers and silicon sequestering effects, Food Res. Int. 43, 2432-2436 (2010).

DOI: https://doi.org/10.1016/j.foodres.2010.09.017 